\title{
Ice conditions in coastal lakes of the southern Baltic Sea
}

\author{
J.P. Girjatowicz \\ Department of Hydrography and Water Management, Szczecin University, Szczecin, Poland, E-mail: girjatjp@ univ.szczecin.pl
}

\begin{abstract}
This paper describes spatio-temporal variability of the basic ice condition parameters, relationships between selected lakes in terms of those parameters, and frequency of fast (ice cover) and floating ice. Attention is also paid to morphology and topography of ice cover in lakes Jamno, Bukowo, Gardno, and Lebsko during 1960/61-1999/2000. Based on data archived at the Institute of Meteorology and Water Management, the following ice parameters were analysed: date of the first ice appearance; date of the first ice cover formation, date of disintegration of the last ice cover, date of disappearance of the last ice, ice season duration, number of days with ice, number of days with ice cover, ice conditions continuity, and maximum ice thickness in winter. Lakes Jamno and Bukowo, located in the western part of the Polish coast, are characterised by milder ice conditions, compared to the more eastward lakes (the Gardno and the Łebsko). Ice parameters were found to correlate closely, with statistical significance exceeding $\alpha=0.01$ and correlation coefficients usually higher than 0.90 , between individual lakes, particularly the neighbouring ones. The highest frequencies of fast and floating ice, 70-75 \% and about $10 \%$, respectively (altogether more than $80 \%$ ), were recorded in the last pentade of January. Fast ice (ice cover), accounting for $80 \%$ of all the ice types, was found to dominate in the lakes studied; fast ice domination is typical of small and shallow water bodies. Ice cover is formed as a result of uniform increase in ice rind thickness. After the fast ice has decayed, an ice field pushed by the wind may form ice piles rising to a few metres above the water surface. At the beginning of the ice season, the piled ice appears most often on the western and northern shores, while at the end of the season it tends to stay on the eastern shores. The processes, associated with the presence of piled ice on the shore, are destructive not only for the shore, but also for constructions deployed within the ice range. The ice piles also affect transport and accumulation of sediment, mainly in the shore zone.
\end{abstract}

Keywords : coastal lakes, southern Baltic, ice conditions parameters, morphology and topography of ice.

\section{Introduction}

Coastal lakes belong to the shallowest water bodies on the southern Baltic coast. Compared to other lakes, they are large and shallow (Choiński 1991, Jańczak 1997). Therefore, they are most susceptible to climatic effects. The lakes heat and cool fairly rapidly, the ice events occurring in them being intensive. Ice conditions in those lakes have not been treated in the literature. Short mentions on ice conditions in the lakes in question can be found in Gołek $(1973,1986)$ and Pasławski (1982). The paucity of literature data could have been a result of omissions and errors in observational data of the Institute of Meteorology and Water Management (IMWM). Those data had to be analysed and verified to detect and correct possible errors; this has already been done (Girjatowicz 2001a).
This work was aimed at describing spatio-temporal variability of the basic ice parameters, their relationships between selected lakes, and frequency of fast (ice cover) and floating ice, as well as at highlighting the morphology and topography of ice cover in those lakes.

\section{Materials and methods}

This work makes use of ice data for the 4 largest southern Baltic coastal lakes: the Jamno (Uniescie), the Bukowo (Bukowo Morskie, the Gardno (Gardna Wiel$\mathrm{ka}$ ), and the Lebsko (Izbica). The data were collected from permanent observation sites shown in Fig. 1. The data, covering the period of 1960/61-1999/2000, were extracted from the IMWM archives. The basic data on morpho- and bathymetry of the lakes are given in Table 1. 


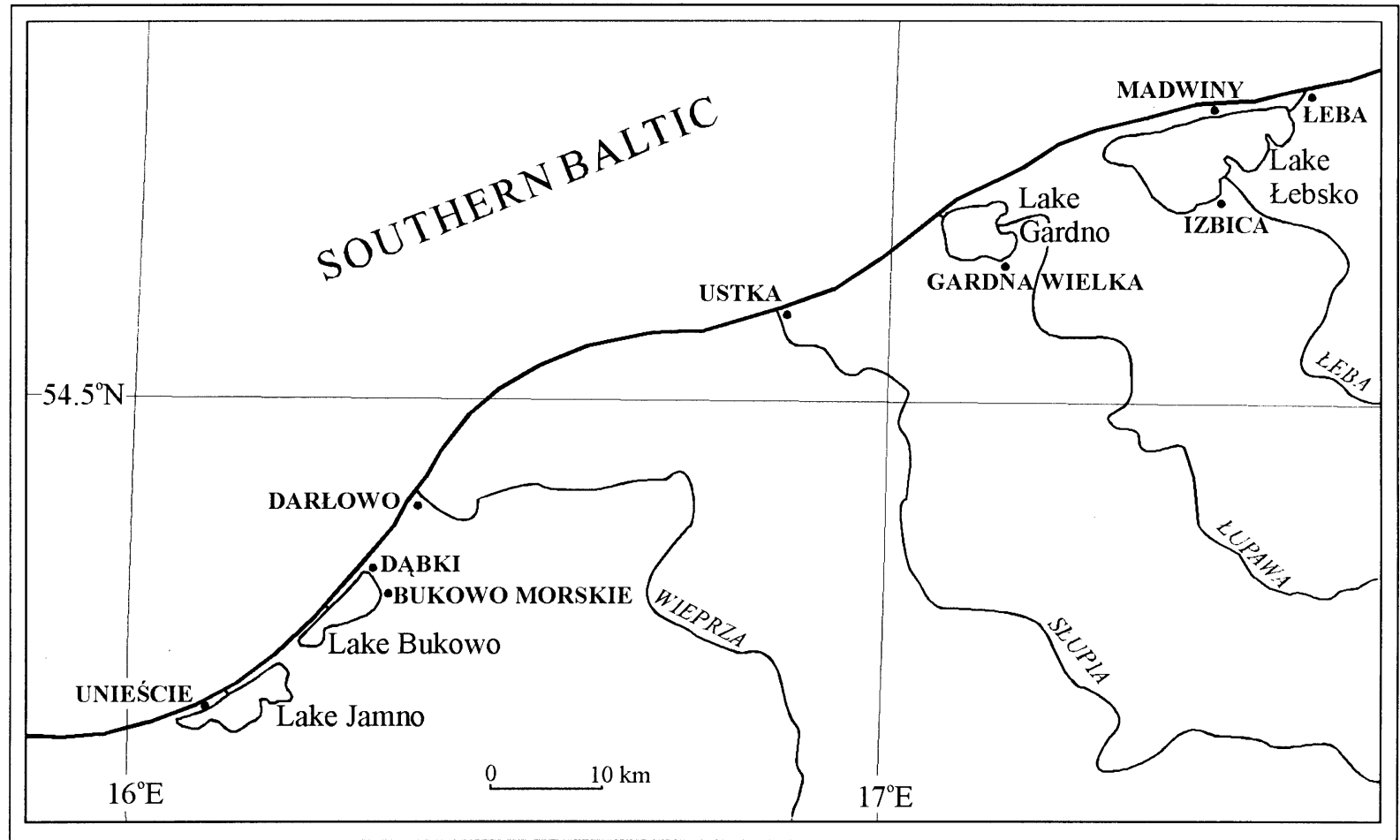

Fig. 1. Location of coastal lakes and observation areas on the southern Baltic coast.

Table 1. Morphometric and bathymetric data for the southern Baltic coastal lakes (after Choiński 1991 \& Janczak 1997).

\begin{tabular}{lcccccc}
\hline Lakes & $\begin{array}{c}\text { Elevation } \\
(\mathrm{m} \text { a.s.l. })\end{array}$ & $\begin{array}{c}\text { Surface area } \\
\left(\mathrm{km}^{2}\right)\end{array}$ & $\begin{array}{c}\text { Volume } \\
\left(\mathrm{km}^{3}\right)\end{array}$ & $\begin{array}{c}\text { Average depth } \\
(\mathrm{m})\end{array}$ & $\begin{array}{c}\text { Maximum } \\
\text { depth(m) }\end{array}$ & $\begin{array}{c}\text { Length of the } \\
\text { shore-line } \\
(\mathbf{k m})\end{array}$ \\
\hline Jamno & 0.1 & 22.4 & 0.032 & 1.4 & 3.9 & 28.3 \\
Bukowo & 0.1 & 17.47 & 0.032 & 1.8 & 2.8 & 23.2 \\
Gardno & 0.3 & 24.68 & 0.031 & 1.3 & 2.6 & 23.3 \\
kebsko & 0.3 & 71.4 & 0.118 & 1.6 & 6.3 & 55.9 \\
\hline
\end{tabular}

For the purpose of this study, the following 9 ice conditions parameters were selected: date of the first ice appearance, date of the first ice cover formation, date of disintegration of the last ice cover, date of disappearance of the last ice, ice season duration, number of days with ice, number of days with ice cover, ice conditions continuity, and the maximum ice cover thickness in a season.

To avoid ambiguities in understanding the terminology applied, the parameters used are defined as follows:

1. Date of the first ice appearance (first ice, F): the date on which any ice form was observed in the area during a season, except for glazing of submerged objects (stones, poles, etc.).

2. Date of the first fast ice formation $(\mathrm{Fc})$ : the date on which fast ice, regardless of its thickness, was observed to cover the entire area (except for current-formed polynyas in river mouths) for the first time in a season.

3. Date of disintegration of the last ice cover (Lc): the date on which disintegration (fractures, polynyas) of fast ice was observed for the last time in a season.

4. Date of the last ice disappearance (last ice, L): the date on which the presence of any ice form (ex- 
cept for grounded ice) was recorded for the last time in a season.

5. Ice season duration: (ice season, $\mathrm{S}$ ): the period of time (days) between the date of the first ice appearance and the date of the last ice disappearance inclusive.

6. Number of days with ice $(\mathrm{N})$ : number of days on which the presence of ice was recorded.

7. Number of days with ice cover $(\mathrm{Nc})$ : number of days on which the presence of fast ice (regardless of its thickness) was recorded over the entire area (except for current-formed polynyas in river mouths); the number of days with ice cover may be equal to or lower than the number of days with ice and the ice season duration $(\mathrm{Nc} \leq \mathrm{N} \leq \mathrm{S})$

8 . Ice conditions continuity $(\mathrm{C})$ : a per cent ratio between the number of days with ice and the ice season duration.

9. Maximum ice cover thickness $(\mathrm{H}, \mathrm{cm})$ : the highest measured thickness of the ice formed as a result of the natural thermodynamic ice growth (except for rafted and piled ice) in a winter.

Definitions of the remaining ice terms can be found in the Sea Ice Nomenclature (WMO 1970).

Relationships between the parameters selected were explored by means of correlation and regression analyses, linear regression equation being developed for the latter. The strength of a relationship was assessed by using correlation coefficients ( $r$ ) and coefficients of determination $\left(\mathrm{r}^{2} 100 \%\right)$. Significance of the relationships was tested using the Fisher-Snedecor test (Czerwiński et al. 1990, Lomnicki 1999).

Ice morphology, and particularly ice thickness, have been studied with different techniques of measurement. Over large areas, air-borne electronic, electromagnetic, and thermometric techniques (Wadhams 1996) have been applied. In the Baltic Sea, it was mainly the Finnish scientists who studied ice cover structure and topography as well as ice piles. Research in the Gulf of Bothnia and in the Gulf of Finland was carried out with the use of ice auger and engine-powered saw (Keinonen 1977), sonar (Palosuo 1976, Keinonen 1976), air and underwater photography (Palosuo 1975), satellite imagery (Uding and Ullerstig 1976), and profilometric laser (Manninen 1996).

In the present work, the simplest technique, i.e., manual drilling of the ice with an auger, was used. Results of drilling served to develop ice profiles along selected sections of an ice cover, including rafted and piled ice forms. Such ice profiles allow to visualise the ice cover structure, thickness, and deformations fairly well (Bruns 1962, Derjugin and Stepanjuk 1974, Leppäranta 1999).

\section{Characteristics of the ice conditions para- meters selected}

Ice conditions parameters archived by IMWM were analysed. Mean and extreme values of the parameters for lakes: Jamno, Bukowo, Gardno, and Lebsko are given in Table 2.

The first ice, most often the ice rind, usually appears in the coastal lakes of the Southern Baltic in the first decade of December (4 - 11 December). It appears earlier in the eastern part of the coast (Lake Lebsko, 4 December); the appearance of the first ice is gradually delayed along the east-west axis (the Jamno: 11 December). The earliest and latest occurrences of the first ice were recorded, overall, in early November and as late as in February, respectively.

The first ice cover was observed to form, on the average, a few to several days later (15-19 December). Occasionally, during periods of strong cooling, a thin ice cover (ice rind) can be perceived as the first ice. An ice cover is a fast ice which, regardless of its thickness, covers the entire lake (Fig. 2). On some occasions, such ice forms were observed at a thickness as low as 1$2 \mathrm{~cm}$.

Although the observer did record an ice cover, mouth areas of rivers and canals could have shown current-formed polynyas. Those usually occur at the beginning of the ice cover formation and when the fast

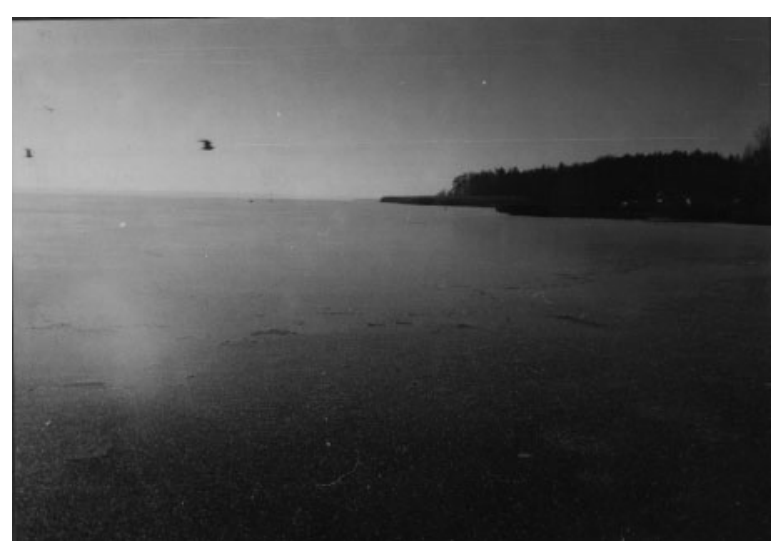

Fig. 2. A thin and flat ice cover in the eastern part of Lake Bukowo (Dabki; 9 Dec. 2002). 
Table 2. Mean and extreme values (1960/61-1999/2000) of selected ice parameters in southern Baltic coastal lakes (Jamno, Bukowo, Gardno, Lebsko).

\begin{tabular}{|c|c|c|c|c|}
\hline Ice parameters & Jamno & Bukowo & Gardno & Kebsko \\
\hline $\begin{array}{l}\text { First ice: } \\
\text { earliest } \\
\text { mean } \\
\text { latest }\end{array}$ & $\begin{array}{c}15 X I \\
11 X I I \\
7 \mathrm{II}\end{array}$ & $\begin{array}{c}11 X I \\
8 X I I \\
7 I I\end{array}$ & $\begin{array}{c}1 \times 1 \\
5 \times 11 \\
6 I I\end{array}$ & $\begin{array}{c}1 X I \\
4 X I I \\
4 \text { II }\end{array}$ \\
\hline $\begin{array}{l}\text { First ice cover: } \\
\text { earliest } \\
\text { mean } \\
\text { latest }\end{array}$ & $\begin{array}{c}15 X I \\
19 X I I \\
15 ~ I I\end{array}$ & $\begin{array}{c}14 X I \\
18 X I I \\
11 ~ I I\end{array}$ & $\begin{array}{c}16 \times 1 \\
15 \times I I \\
16 ~ I I ~\end{array}$ & $\begin{array}{c}19 \text { XI } \\
17 \text { XII } \\
13 \text { II }\end{array}$ \\
\hline $\begin{array}{l}\text { Last ice cover: } \\
\text { earliest } \\
\text { mean } \\
\text { latest }\end{array}$ & $\begin{array}{l}7 \mathrm{XII} \\
28 \mathrm{II} \\
13 \mathrm{IV}\end{array}$ & $\begin{array}{l}8 \text { XII } \\
1 \text { III } \\
7 \text { IV }\end{array}$ & $\begin{array}{c}19 \text { XII } \\
1 \text { III } \\
9 \text { IV }\end{array}$ & $\begin{array}{c}13 \text { XII } \\
2 \mathrm{III} \\
10 \mathrm{IV}\end{array}$ \\
\hline $\begin{array}{l}\text { Last ice: } \\
\text { earliest } \\
\text { mean } \\
\text { latest }\end{array}$ & $\begin{array}{c}10 \mathrm{XII} \\
7 \mathrm{III} \\
13 \mathrm{IV}\end{array}$ & $\begin{array}{c}22 \text { XII } \\
8 \text { III } \\
17 \text { IV }\end{array}$ & $\begin{array}{c}24 \mathrm{XII} \\
12 \mathrm{III} \\
19 \mathrm{~N}\end{array}$ & $\begin{array}{c}22 \text { XII } \\
11 \mathrm{III} \\
17 \mathrm{IV}\end{array}$ \\
\hline $\begin{array}{l}\text { Duration of ice season (days): } \\
\text { shortest } \\
\text { mean } \\
\text { longest }\end{array}$ & $\begin{array}{c}0 \\
85 \\
134\end{array}$ & $\begin{array}{c}0 \\
89 \\
139\end{array}$ & $\begin{array}{c}30 \\
98 \\
160\end{array}$ & $\begin{array}{c}24 \\
98 \\
159\end{array}$ \\
\hline $\begin{array}{l}\text { Days with ice: } \\
\text { minimum } \\
\text { mean } \\
\text { maximum }\end{array}$ & $\begin{array}{c}0 \\
68 \\
133\end{array}$ & $\begin{array}{c}0 \\
73 \\
139\end{array}$ & $\begin{array}{c}15 \\
77 \\
142\end{array}$ & $\begin{array}{c}13 \\
74 \\
142\end{array}$ \\
\hline $\begin{array}{l}\text { Days with ice cover: } \\
\text { minimum } \\
\text { mean } \\
\text { maximum }\end{array}$ & $\begin{array}{c}0 \\
57 \\
129\end{array}$ & $\begin{array}{c}0 \\
59 \\
134\end{array}$ & $\begin{array}{c}2 \\
61 \\
136\end{array}$ & $\begin{array}{c}0 \\
58 \\
123\end{array}$ \\
\hline $\begin{array}{l}\text { Continuity of ice conditions } \\
(\%) \text { : } \\
\text { minimum } \\
\text { mean } \\
\text { maximum }\end{array}$ & $\begin{array}{c}27 \\
80 \\
100\end{array}$ & $\begin{array}{c}33 \\
81 \\
100\end{array}$ & $\begin{array}{c}20 \\
78 \\
100\end{array}$ & $\begin{array}{c}17 \\
77 \\
100\end{array}$ \\
\hline $\begin{array}{l}\text { Maximum ice thickness }(\mathrm{cm}) \text { : } \\
\text { lowest } \\
\text { mean } \\
\text { highest }\end{array}$ & $\begin{array}{c}0 \\
22 \\
45\end{array}$ & $\begin{array}{c}0 \\
23 \\
52\end{array}$ & $\begin{array}{c}4 \\
24 \\
48\end{array}$ & $\begin{array}{c}3 \\
23 \\
52\end{array}$ \\
\hline Winters without ice & 1 & 1 & 0 & 0 \\
\hline
\end{tabular}


ice disintegrates. If the ice cover is thin, the polynyas may reach several hundred metres into a lake, particularly in the mouth of larger rivers (Leba, Lupawa). Shorter polynyas, predominantly up to several tens of metres long, may form where a river or a canal discharges into a lake.

The last ice cover disintegrates usually in late February-early March (28 February - 2 March). The ice cover on the lakes studied usually disintegrates when it is from a few to several $\mathrm{cm}$ thick, depending on the maximum ice thickness (extent of decay) and wind force. At the extreme, the ice cover disintegrates at the latest between the first and second decade of April (7 13 April).

The last ice disappears usually at the turn of the first and second decade of March (7 - 12 March). At the extreme, the latest disappearance of ice (ice floe and brash ice) disappears as late as in the second decade of April (13-19 April). The last ice disappears usually a few days earlier in the western part of the coast (lakes Jamno and Bukowo), compared to the eastern part (the Gardno and Lebsko). Due to the prevalence of westerly winds, the ice disappears mostly on the eastern shores (Fig. 3).

Duration of the ice season depends on the dates of appearance and disappearance of ice, as the ice season is defined as a period of time (number of days) between the date of the first ice appearance and the date of the last ice disappearance inclusive. The average duration of the ice season ranged from 85 to 98 days and the longest seasons persisted from 134 to 160 days. The ice season is clearly longer in the eastern part of

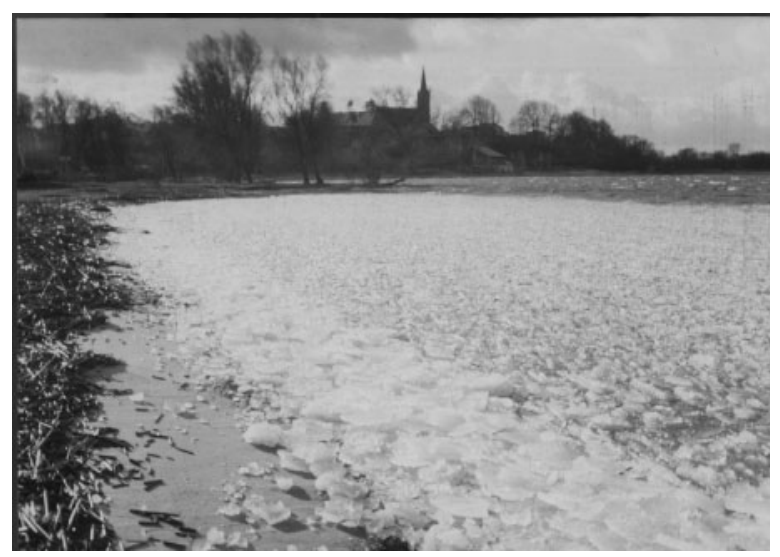

Fig. 3. Thawing brash ice on the eastern shore of Lake Gardno (Gardna Wielka; 25 Jan. 2002). the coast (lakes Gardno and Lebsko) than in the western part (the Jamno and the Bukowo). The ice season was absent (no ice on the lake) in the western part of the coast (the Jamno and the Bukowo) only during the very mild winter of $1974 / 75$. On the other hand, during that winter, the ice season in the eastern part of the coast lasted from 74 (the Gardno) to 75 days (the Lebsko).

Similarly to the ice season, the number of days with ice is higher in the eastern part of the coast, compared to the western part. Usually, there are from 68 such days in the Jamno to 77 in the Gardno. The highest numbers of days were 133 and 142, respectively, the respective lowest numbers being 0 and 15 .

The number of days with ice cover (fast ice) was by several days lower than the total number of days with ice. Its average values ranged from 57 (the Jamno) to 61 (the Gardno). The highest numbers of days with ice cover were found to range within 123-136, the lowest numbers ranging within 0-2. It was only on the shallowest Lake Gardno that the ice cover was present each year during the period examined.

The ice conditions continuity, defined as a per cent ratio between the number of days with ice and the ice season duration, is highest in smaller lakes (the Bukowo and the Jamno). The average ice conditions continuity was observed to range from $77 \%$ (the Lebsko) to $81 \%$ (the Bukowo). The highest values recorded amounted to $100 \%$, when the number of days with ice was equal to the ice season duration. The lowest values were found to range from $17 \%$ (the Lebsko) to $33 \%$ (the Bukowo). The relatively large and deep lakes, characterised by a more intensive water dynamics, showed the longest gaps between periods of ice cover, hence their lowest ice conditions continuity.

The maximum ice cover thickness, defined as the largest thickness in individual winters, was somewhat higher in the eastern part of the coast than in the western part. The average maximum thickness ranged from 22 $\mathrm{cm}$ in the Jamno to $24 \mathrm{~cm}$ in the Gardno. The highest maximum thickness of $45 \mathrm{~cm}$ in the Jamno and $52 \mathrm{~cm}$ in the Bukowo and Lebsko were recorded in the very severe winters of 1969/70 and 1978/79, respectively.

The analysis presented shows more severe ice conditions to be typical of the lakes situated in the eastern part of the coast. Almost all the ice conditions parameters (except for the ice conditions continuity) were higher in the eastern part (lakes: Gardno and Lebsko) than in the western part (the Jamno and the Bukowo). The pattern observed results primarily from climatic conditions that are somewhat more severe in the eastern part. 
Along the southern coast of the Baltic Sea, a pronounced eastward decrease of air temperature is observed in winter. For example, the February air temperature in the south-western part of the Baltic is about $1{ }^{\circ} \mathrm{C}$ to decrease to about $-3^{\circ} \mathrm{C}$ in the south-eastern part (Malicki \& Mietus 1994). With respect to the lakes studied, the winter air temperature decrease amounts to about $0.5^{\circ} \mathrm{C} / 100 \mathrm{~km}$ (Stopa-Boryczka et al. 1990). Continental climate effects, visible as increasing thermal contrasts (increasingly warmer summers and increasingly severe winters) grow in intensity as one moves eastwards along the coast. This is reflected in increasing indices of thermal continentalism (Ewert 1963, Woś 1967) and decreasing indices of oceanicity in the eastward (Stopa-Boryczka et al. 1994, Marsz 1995).

In the eastern part, more severe ice conditions occurred in Lake Gardno than in the Lebsko, although the latter is located more eastward. The Gardno is the shallowest of the lakes studied (Table 1) and the bathymetry was most likely decisive for development of the most severe ice conditions in that lake.

\section{Relationships between ice condition para- meters}

The high similarity between the lakes studied in terms of their ice conditions, particularly pronounced between the neighbouring lakes, is confirmed by strong correlations between their ice conditions parameters. The relationships are presented in an orthogonal system of coordinates, with a $99 \%$ confidence interval, for the lakes located farthest apart, i.e., between the Jamno and the Lebsko. The relationships of the following ice conditions parameters were explored (Fig. 4): date of the first ice (F) and date of disappearance of the last ice $(\mathrm{L})$, number of days with ice cover $(\mathrm{Nc})$, number of days with floating ice (Nf), total number of days with ice $(\mathrm{N})$, duration of ice season $(\mathrm{S})$, maximum ice thickness $(\mathrm{H})$, and continuity of ice conditions (C). All the relationships proved statistically significant, even at $\alpha=0.01$.

The highest (exceeding 0.90), correlation coefficients between the two lakes (the Jamno vs. the Lebsko) were obtained for the number of days with ice $(\mathrm{N})$, number of days with ice cover $(\mathrm{Nc})$, date of disappearance of the last ice $(\mathrm{L})$, and the maximum ice thickness $(\mathrm{H})$. Variation in the number of days with ice in the Jamno is in $93 \%$ determined by the variation in that number in the Lebsko. On the other hand, an increase in the number of days with ice by one unit (day) in the Lebsko is reflected in a similar increase (0.97) of the parameter in the Jamno. The strong correlation between those parameters between the two lakes can be explained by the similarity of their physiography, a short distance between them, and similar climatic conditions.

The weakest correlations between the two lakes (the Lebsko and the Jamno) are those involving the number of days with floating ice $(r=0.596)$ and date of the first ice $(r=0.709)$. The correlation between the respective numbers of days with floating ice may be affected fairly substantially by certain local, non-thermal, factors, mainly the wind (advance or recession of ice). It has to be mentioned that the observations on the Jamno were carried out on its northern shore (Unieście), the southern shore (Izbica) being the observation site on the Lebsko. A southerly wind may cause the ice to advance in one of the areas and to recede in the other.

The weaker correlations between dates of the first ice, particularly between the lakes located farthest apart, may be affected by the initial temporary cooldown which may cause the first ice to form in one part of the coast (e.g., eastern), an effect absent from the other part (e.g., western). Temporal differences between dates of the first ice depend on the occurrence of the next cool-down period and the formation of the first ice in the remaining lakes. The more different are the dates in the lakes studied, the weaker the correlations between them.

\section{Frequency of ice}

Frequency of the occurrence of selected ice conditions: fast ice (ice cover) and floating ice, and the relevant course of events in different winters of the 40year-long period examined (1960/61-1999/2000) was plotted, by pentades, for the largest lake, i.e., the Lebsko (Fig. 5). The floating ice includes not only grease ice, floe, or brash ice, but also shore ice and an incomplete ice cover.

The plots for the remaining coastal lakes showed no basic differences with the Lebsko plot. The frequency of occurrence of ice in different pentades as well as the time course of the ice events discussed in individual winters was similar in all the lakes. The highest frequency $(85 \%)$ was recorded in the last pentade of January (Fig. 5). At that pentade, fast and floating ice occurred at frequencies of 75 and $10 \%$, respectively. A period from the fourth pentade of December until the third pentade of March is distinct in that the ice events discussed are more frequent that every other winter 

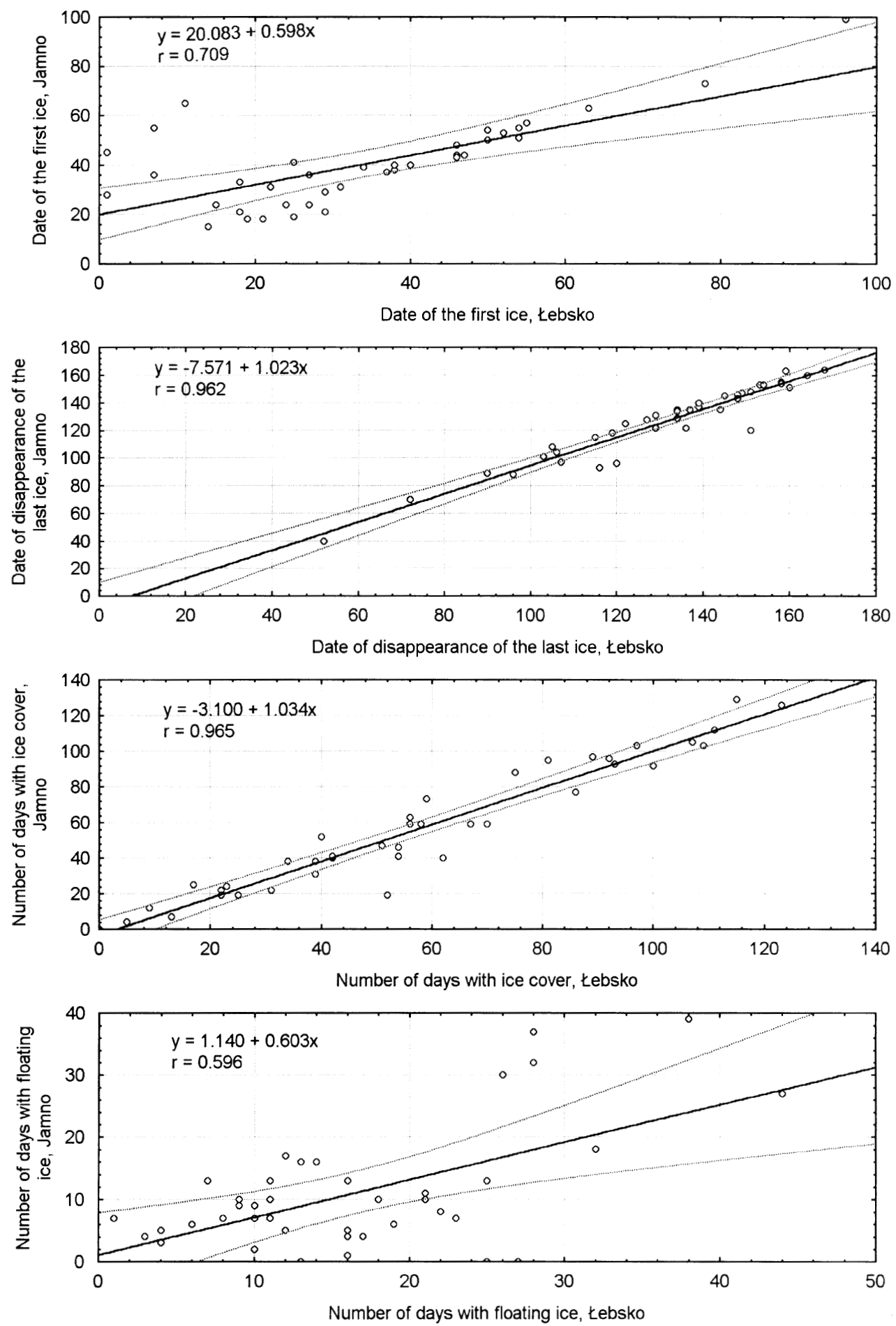

Fig. 4. Relationships of selected ice parameters between the coastal lakes Lebsko and Jamno over 1960/61-1999/2000 (see text for explanation). 

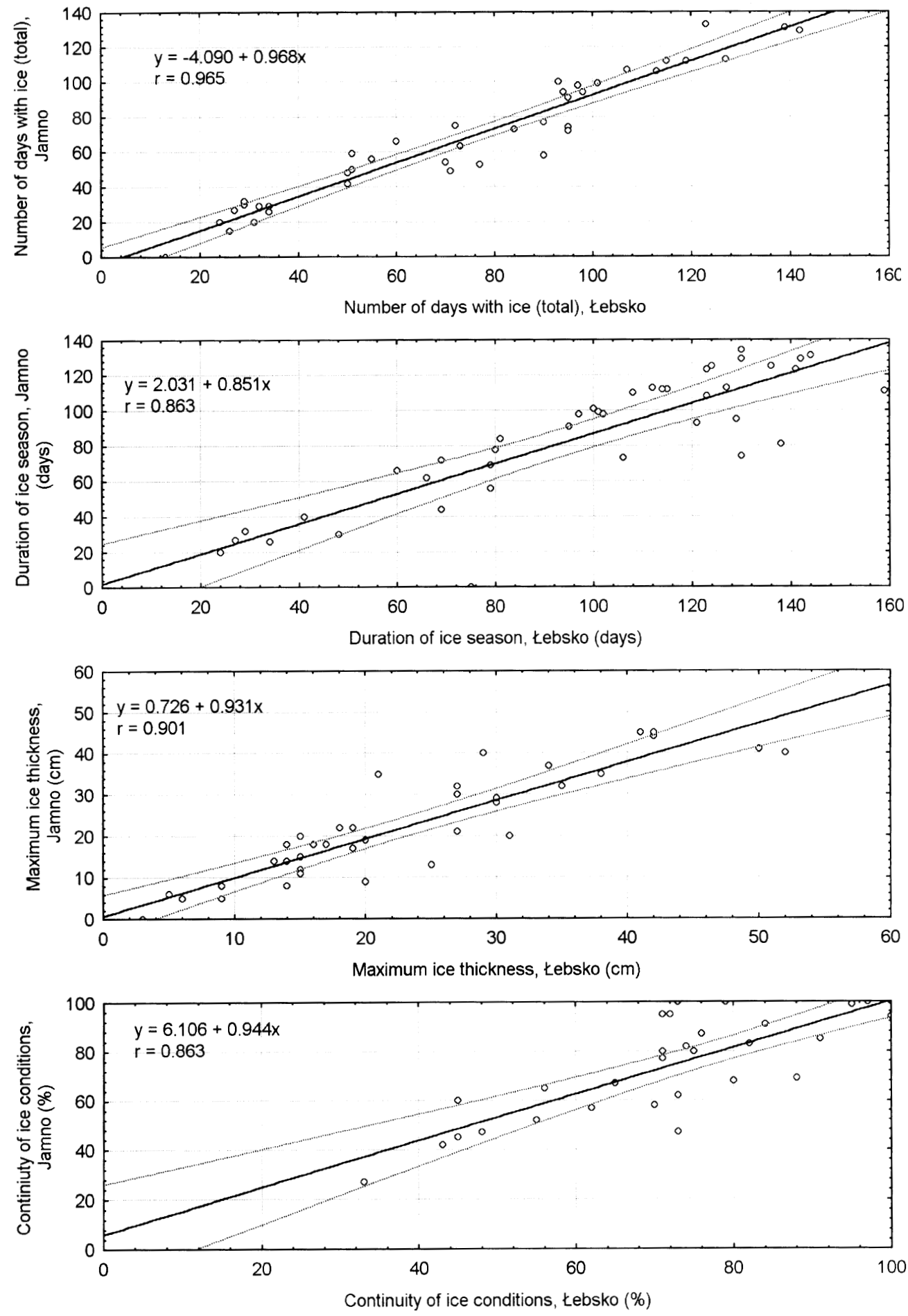

Fig. 4 (continued). Relationships of selected ice parameters between the coastal lakes Lebsko and Jamno over 1960/61-1999/2000 (see text for explanation). 
(>50\%). Fast ice, too, occurred at a similar frequency at that period (Fig. 5).

The ice season showed a pronounced domination of fast ice $(80 \%)$ over floating ice $(20 \%)$. The frequency of fast ice, from the fourth decade of November until the end of January, tended to increase, and decreased thereafter until the ice disappeared in the second pentade of April. On the other hand, the frequency of floating ice showed no clear changes between the pentades, the ice dominating only at the beginning and at the end of the ice season (Fig. 5).

The plot in Fig. 5 shows also an increase, during the recent decades, in the number of short ice periods. An ice period is a continuous sequence of days with ice. In the 1980 s and 1990s, there were usually 2 - 4 ice periods per winter. On the other hand, earlier decades (e.g., the 1960s) were dominated by winters having usually one or two long ice periods. Long and sparse ice periods are typical of severe and moderate winters. Recently, short and fairly numerous ice periods, appearing at different time in winters, have been typically recorded. They are characteristic of mild winters and evidence of climate warming and ice conditions becoming less severe. Similarly, the ice cover duration has become shorter and shorter, the ice cover tending to form and disintegrate more often during a winter. This is a consequence of not only a more frequent appearance of thinner ice cover, but results also from frequent changes in meteorological conditions manifested as, i.a., frequent alteration between periods of cooling $\left(\mathrm{t}<0^{\circ} \mathrm{C}\right)$ and warming $\left(\mathrm{t}>0^{\circ} \mathrm{C}\right)$.

Numerous authors have pointed out that ice conditions within the Baltic Sea basin are becoming milder and milder (Leppäranta \& Seina 1985, Seina \& Palosuo 1993, Girjatowicz \& Kożuchowski 1995, Koslowski \& Glaser 1999). Preliminary research in the lakes studied, too, resulted in revealing a trend towards reduction in ice parameters. For example, the number of days with ice in Lake Jamno was observed to decrease at a rate of 1 day/year within 1955/56 1999/2000.

\section{Morphology and topography of ice cover}

The degree of water surface turbulence in the wellsheltered and small coastal lakes is slight only. For this reason, the conditions enhancing ice rind formation are prevalent. The accreting ice rind gives rise to an ice cover the thickness of which may even exceed $0.5 \mathrm{~m}$ in severe winters (Table 2). The ice covers formed by ice rind accretion do not disintegrate easily. The accretion has usually been uniform, producing ice of a homogenous structure, cohesive, and smooth on the surface. A high resistance of such cover, its large thickness, and slack water movements (due to the small size of the lakes) do not enhance ice cover deformation. Therefore, such ice covers disintegrate in spring, once the ice has largely thawed. If heavy wind prevails during this period, rafted and piled ice may appear.

The ice profiles explored during field studies of various lake areas in winters of 1999/2000-2002/2003 supplied valuable information on morphology and topography of ice covers. Rafted and piled ice was found to appear on the coastal lakes not only after disintegration of the stable ice cover, but also before it is formed. Such a situation occurs usually at the beginning of the ice season. Patches of ice rind begin to drift, pushed by heavy wind, and rafted and piled to the windward. Ice piles appeared usually near the shore - along it or along the margin of the fast shore ice. On the other hand, rafted ice occurs usually on the forefront of the piles. As a result, the emerging ice cover has, on the lake's windward side, an uneven, rough surface with numerous raftings and small piles (the pile height is primarily dependent on the ice thickness). On the other hand, the ice cover on the leeward, forming under sheltered conditions, has a relatively smooth surface.

An example of such topographic variation is furnished by the ice cover formed on the coastal lakes in the winter of 2002/2003. When the ice rind was being formed, a fairly heavy wind, mainly from the south-east, occurred and during 6-7 December the ice rind patches were moved towards the northern shores of the lakes. The ice rind had a low thickness, from $0.5 \mathrm{~cm}$ on the Jamno to $2 \mathrm{~cm}$ in the Lebsko. In spite of that, the rafted ice thickness, and particularly that of the piled ice in the Jamno stuck out to $0.5 \mathrm{~m}$ above the water surface (Fig. 6), and even to more than $1 \mathrm{~m}$ at some sites in the Lebsko.

The highest pile was a grounded hummock $1.5 \mathrm{~m}$ above the water level high, formed on the edge of the Lebsko shore bank near Madwiny (Fig. 7). The hummock consisted of ice rind plates, mainly on the windward side, and of brash ice to the leeward (shoreward). The windward and leeward sides were sloping at about $30^{\circ}$ and $20^{\circ}$, respectively (Fig. 8). The hummock showed two ridges, differing slightly in their altitudes. The higher altitude of the shoreward ridge resulted most probably from the smaller depth, because the pile had formed on the slope of the bank.

The southern, and particularly the south-eastern parts of the lakes, initially ice-free, developed a fast ice rind, too, with a 1-day delay. The ice rind formed at 


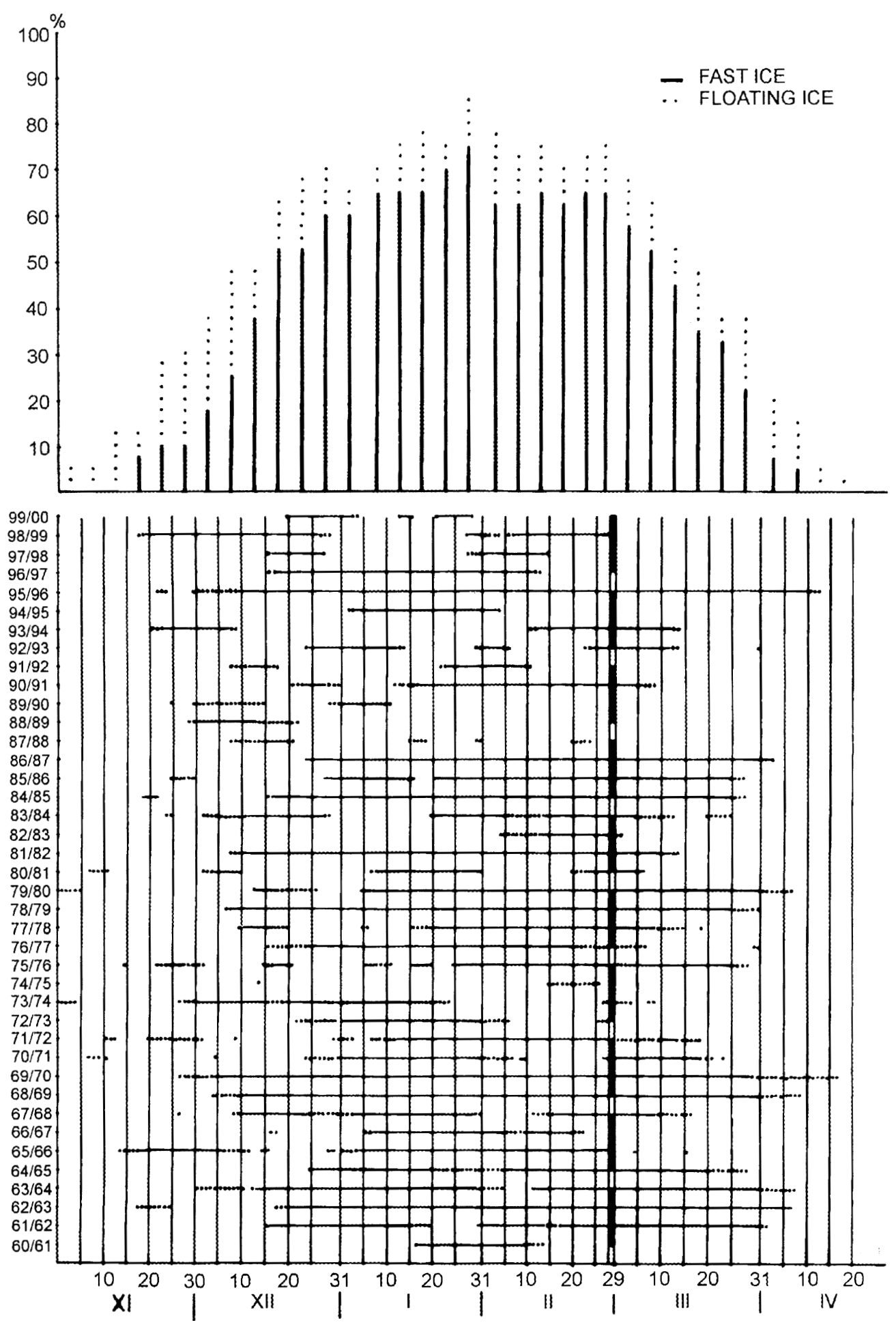

Fig. 5. A plot of pentade frequency (\%) of days with fast ice and floating ice for Lake Lebsko (Izbica) over 1960/61-1999/2000. 


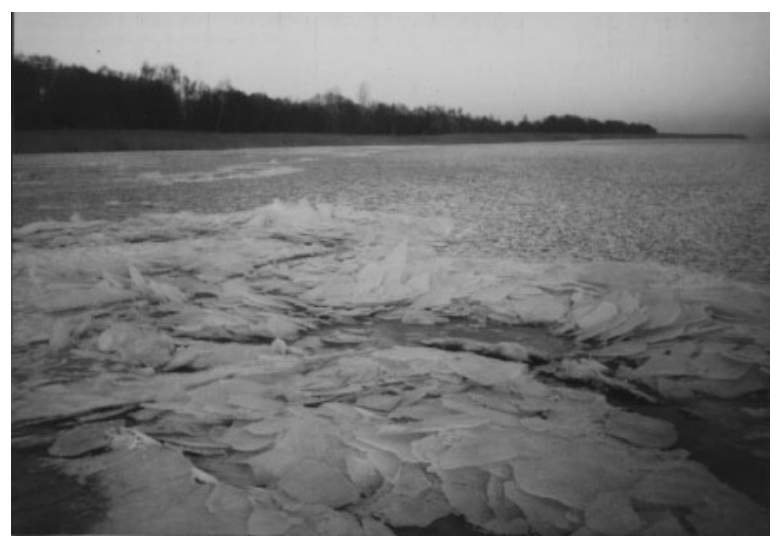

Fig. 6. Piled ice rind in the northern part of Lake Jamno (Unieście; 9 Dec. 2002)

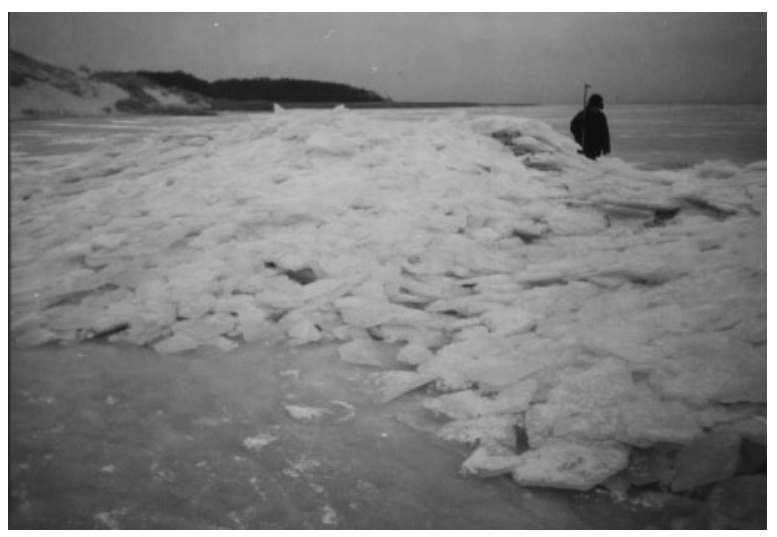

Fig. 7. Grounded hummock on the northern shore of Lake Lebsko (Madwiny, 10 Dec. 2002).

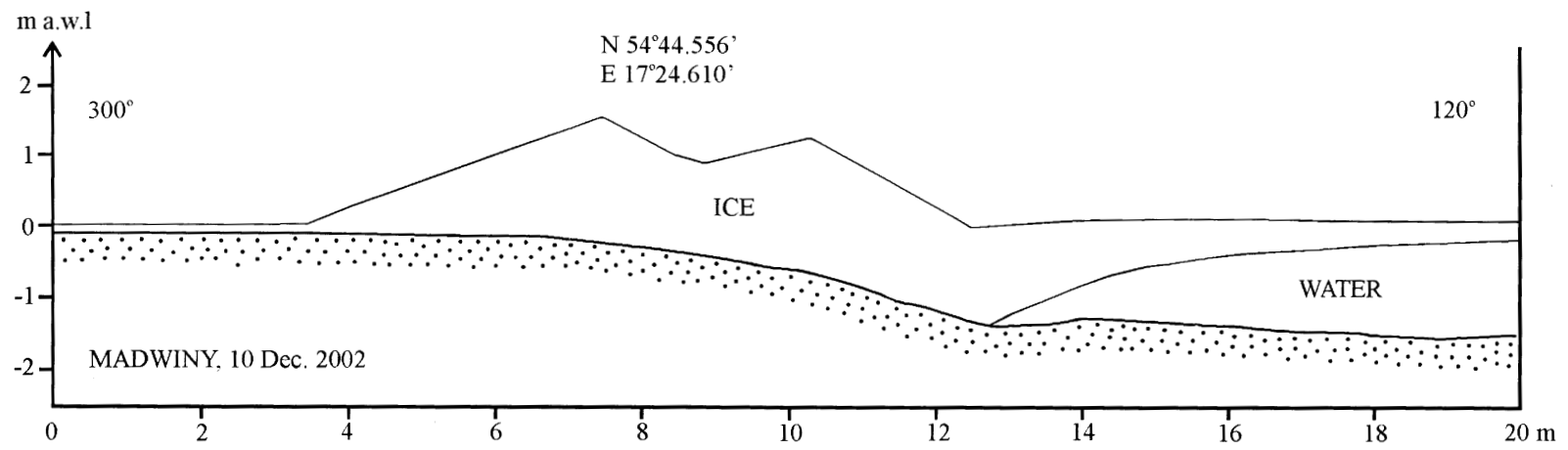

Fig. 8. A cross-section through a grounded hummock on the northern shore of Lake Lebsko (Madwiny; 10 Dec. 2002).

more sheltered conditions, so its surface was smoother (Fig. 2).

With time, the ice cover thickness, both in the southern and in the northern part of the lakes, became uniform. The raftings and piles, consolidated in the ice cover, were observed to intensively thaw out, particularly in their submerged parts. For example, the thickness of the Jamno ice cover was, after 3 weeks, almost identical at the piles and beyond them (Fig. 9), the differences in thickness not exceeding $10 \mathrm{~cm}$. Fig. 10 shows two ice profiles, explored at the same site, but at a 21-day interval (27 December - 16 January). The piles thawed out and the ice thickness levelled off along the profile mainly due to periods of warming (27-30 December 2002 and 12-16 January 2003). The former piling sites were distinguishable chiefly because of the milky colour (because of the high amount of air bubbles of the ice), set off against the darker coloration of the surrounding, transparent, ice. (Fig. 10). In addition to having a higher albedo, such white ice lets much less solar radiation into the water column.

Grounded piles, particularly those located closer to the shore, thaw at a much slower rate. The less they are submerged, the longer they stay. Persistence of ice piles depends not only on the depth of a site they have formed at, but also on their altitude above the water level, type of ice they emerged from, and hydro-meteorological factors (air and water temperature, intensity of solar radiation, wind).

Piled ice thaws most intensively in its submerged part, even at below-zero air temperatures. During periods of warming and strong wind, thawing and lowering of the pile is faster and accelerates when the ice cover disappears and the pile remains alone on the wa- 

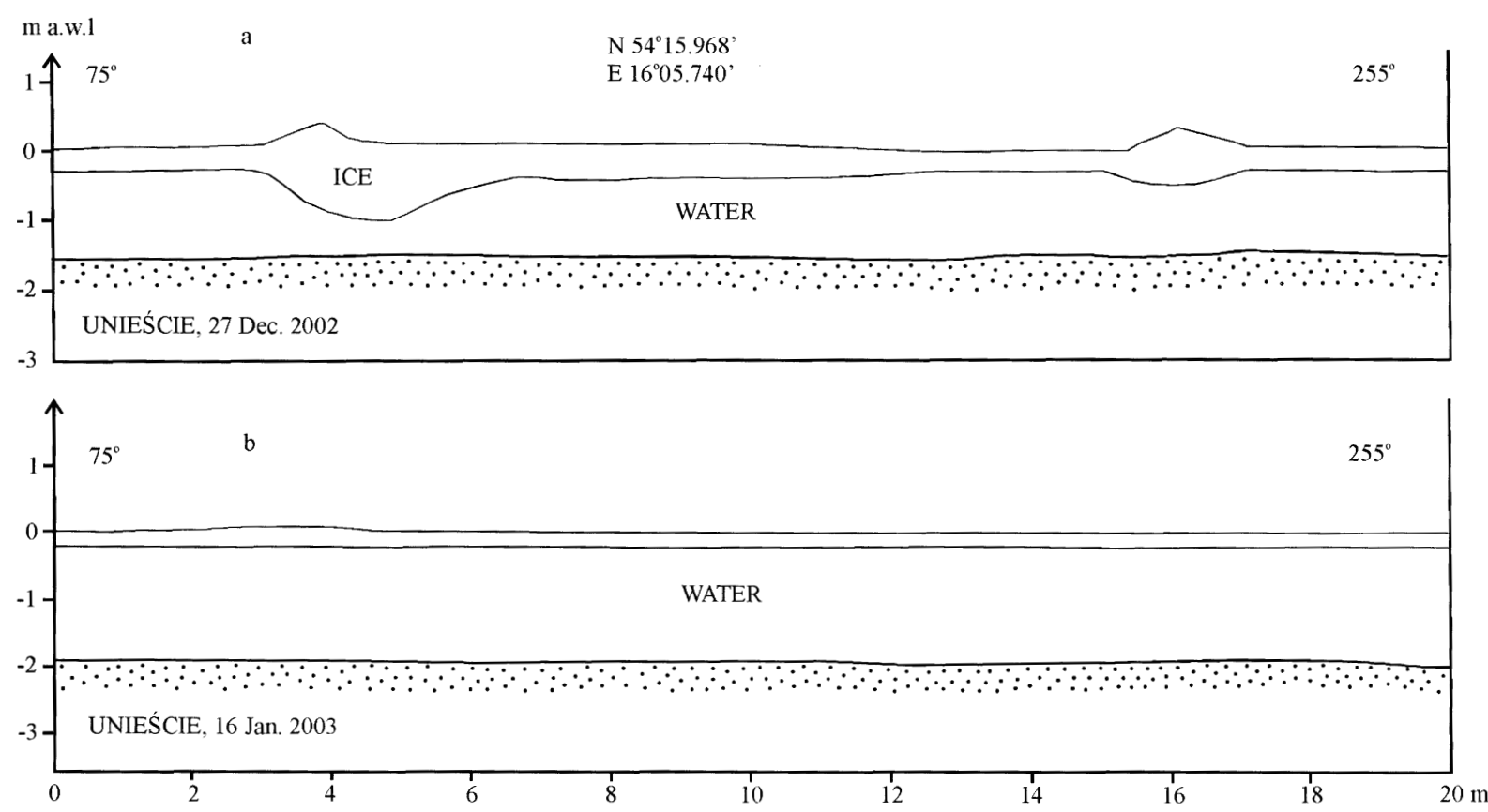

Fig. 9. Cross sections through ice cover with small ice rind piles (a) and after their thawing (b) in the northern part of Lake Jamno (Unieście).

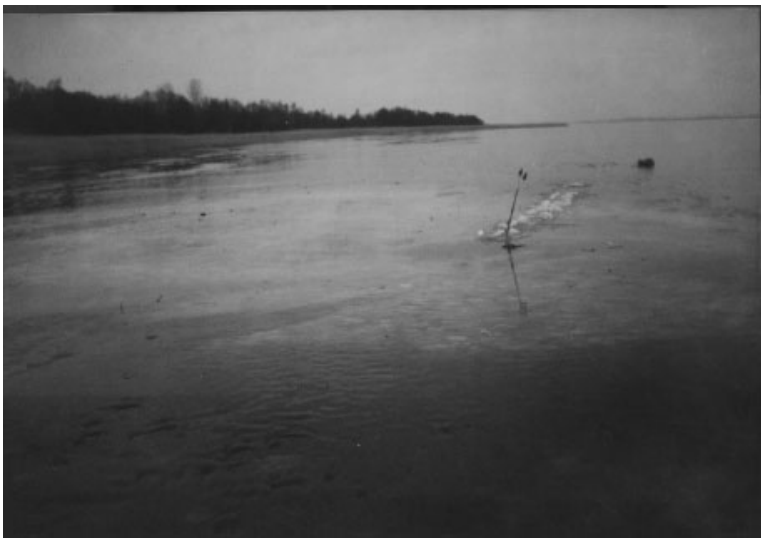

Fig. 10. A thawing ice cover with a visible lighter hue, evidencing former, already thawed out, ice rind piles (Unieśsie; 16 Jan. 2003).

ter. Then, due to wave action and undercutting, the pile disintegrates into brash ice. As a result, the hydrostatic equilibrium of the pile is disturbed and it rapidly breaks down, leaving behind an accumulation of floating brash ice that disappears fast.

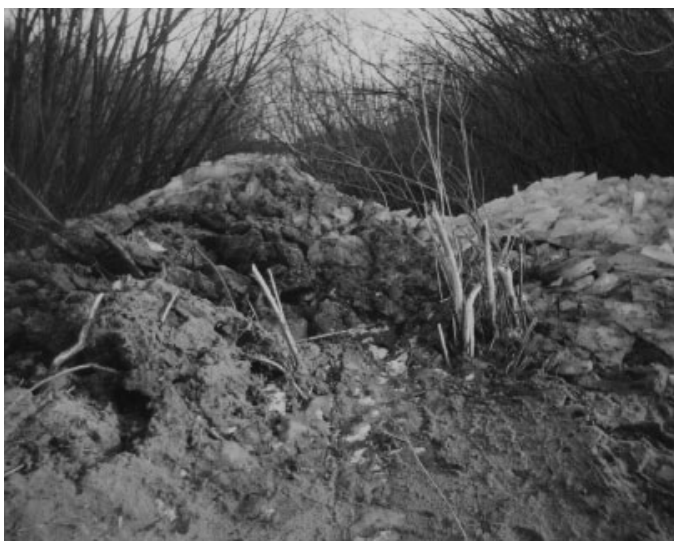

Fig. 11. Sediments thawed out from a hummock on the eastern shore of Lake Lebsko (River Leba mouth; 25 Jan. 2002).

The slowest to thaw are those ice piles that have been formed on land. Their thawing depends mainly on air temperature and solar radiation intensity. While thawing, the ice releases sediment particles that accumulate on the ice surface, imparting a darker and dar- 
ker hue to it (Fig. 11). After thawing is complete, a grey-brown or brown deposit, consisting of sand, peat, mud, plants, and shells as well as bird feathers and faeces, remains.

Where the rafted and piled ice appears in the lake depends mainly on wind direction. At the onset of the ice season, when heavy easterly winds prevail, the rafted and piled ice appears in the western and northern parts of the lake. Thin ice rind plates, drifting eastwards, are piled up in the shore zone to not higher than $2 \mathrm{~m}$ above the water level. On the other hand, towards the end of the ice season, once the ice cover has disintegrated, when strong westerly winds prevail, deformed ice occurs usually in the eastern part of the lake. The ice piles may be up to a few metres above the water level high, depending on the ice thickness and wind speed.

\section{Conclusions and observations}

The coastal lakes of the southern Baltic are relatively shallow, for which reason they develop intensive ice phenomena. The ice appears early in those lakes, persists for a prolonged periods of time, disappears late, and occurs in the form of thick ice covers. Among the remaining areas of the southern Baltic coast, more severe ice conditions occur only in the Curonian and Vistula Lagoons (cf. Lundbeck 1931, Zorina \& Malinski 1975, Sergeyeva 1983). Conditions similar to those prevalent in the lakes have been observed in the Small Puck Bay (cf. Zakrzewski \& Szefler 1984, Szefler 1993). Milder ice conditions have been observed in the Szczecin Lagoon (cf. Malinski 1971, Correns 1973), while much milder conditions are typical of the southern Baltic shores (cf. Bluthgen 1953, «Eishandbuch»... 1972, Girjatowicz 1990). In coastal lakes and lagoons, ice conditions grow in intensity and their frequency increases eastwards; ice parameter coefficients of variation decrease, and correlations between thermal and circulation conditions and ice parameters assume higher coefficients (Girjatowicz 2001b, 2003).

Relationships between the same ice parameters, explored for different southern Baltic areas are strongest in shallow regions, such as the coastal lakes. Equally strong are the correlations between similar areas, e.g., between Lake Dabie and Roztoka Odrzańska (Girjatowicz 1981) or between the southern Baltic coastal lagoons, with correlation coefficients exceeding 0.90 (Girjatowicz 1983, 1994). Weaker, although statistically significant, are correlations for offshore areas, particularly those located close to Baltic deeps (e.g., parts of the Gulf of Gdansk; Girjatowicz 1983). In those relatively deep and exposed areas, clearly differentiated in terms of their local conditions, non-thermal factors such as water movement and/or wind (advance or recession of ice) which weaken the correlations are important. On the other hand, in small, shallow areas similar in their physiography, non-thermal effects on the correlations are only slight. Ice events in those areas are strongly dependent on thermal conditions. The ice appears, persists, and disappears almost at the same time. Therefore, the correlations between those areas in terms of individual ice parameters are close.

Along the southern Baltic coast, it is only in the eastern coastal lagoons that various ice phenomena appear more frequently than in the coastal lakes. The maximum frequency of ice in the Curonian and Vistula Lagoons in January and February may be as high as $100 \%$ (Zorina \& Malinski 1975). The maximum frequency of ice in all the southern Baltic coastal areas is recorded usually in late January-early February. It is the coastal lakes only that the maximum frequency is observed in the last pentade of January.

Similarly to other small, shallow, and sheltered areas, the coastal lakes most often develop level ice covers as a result of ice rind uniformly increasing in thickness. Those ice covers are clearly different from those evolving near the southern Baltic coast. In those exposed areas, an ice cover is usually formed from compressed consolidated grease ice and shuga or from compressed and consolidated floe and brash ice (Girjatowicz 2001c). In the northern Baltic, such ice covers, similar in appearance to packed ice, may account for up to $50 \%$ of all the ice surface (Leppäranta 1998). Ice cover topography is more diverse in marine areas than in the lakes. Rafted and piled ice is observed more seldom in the latter, also the pile altitude is lower in the lakes than in the lagoons and near the shore: ice hummocks may be as high as $10 \mathrm{~m}$ above the water level in the lagoons (Zimdars 1941, Girjatowicz 2001d) and even up to several metres near the Baltic coast (Slaucitajs 1929, Bluthgen 1954, Reinhard 1955).

Climate warming, intensification of zonal circulation, and increased frequency of deep atmospheric lows (Kożuchowski 1995) will enhance frequent disintegration of ice covers. The accompanying strong winds will induce intensified drift of ice fields. The ice advancing upon the shore will produce adverse effects not only on shore reinforcement, trees, and shrubs, but also on man-made constructions on the shore.

In addition to the cognitive value, the results presented can be of a practical importance. The knowledge on dates and periods of ice presence can be taken advantage of when planning activities related to navigation and fisheries. Data on ice conditions can be also used when designing water infrastructure. 
Depending on its form, thickness, and snow cover thickness, the ice present in a water body affects, to a larger or smaller degree, the biological properties of a reservoir. Clear ice presents no particular obstacle to penetration of solar radiation into the water column and to phytoplankton growth (Wetzel 1975). On the other hand, the penetration is strongly reduced when the ice contains air bubbles, and particularly when it is covered by snow. A fresh, $20 \mathrm{~cm}$ thick snow cover may absorb and reflect up to $99 \%$ of the incident solar radiation. Such a snow cover strongly restricts photosynthesis under the ice (Lampert \& Sommer 1996). It may be presumed that opaque ice forms such as slush, shuga, pancake ice, rafted and piled ice restrict light penetration into the water column as well. The ice cover forms also a barrier for oxygen diffusion into the water, for which reason an ice-bound water body frequently develops hypoxic, or even anoxic, conditions (Stańczykowska 1990, Kajak 1995). It may be presumed that hypoxia and anoxia in flow-through areas covered by transparent and/or floating ice will be greatly limited. As ice becomes less compact, oxygen availability in and diffusion to the water column should increase. Unfortunately, no research on biology and chemistry of the Baltic coastal lakes during the ice season has been carried out so far. Such research would be of value both for science and for economy.

\section{Acknowledgements}

The author would like to express his gratitude to anonymous referees for their efforts in improving the manuscript.

\section{References}

Blüthgen J. 1954. — Die Eisverhältnisse der Küstengewässer von Mecklenburg-Vorpommern. Forschungen zur Deutschen Landeskunde, 85.

Bruns E. 1962. - Ozeanologie. Berlin.

Choiński A. 1991 - Katalog jezior Polski. [Catalogue of Polish Lakes]. Wyd. Naukowe Uniwersytetu im. A. Mickiewicza, Poznań (in Polish).

Correns M. 1973 — Eisverhältnisse des Peenestrom-Haffgebietensein Beitrag zur Hydrographie der Gewässer an der Sädlichen Ostseeküste. Petermanns Geographischen Mitteilungen, 117, (4).

Czermiński J., Iwasiewicz A., Paszek Z. \& Sikorski A. 1990. — Statistical methods in applied chemistry. Elsevier, Amsterdam-Oxford-New York-Tokyo.

Derjugin K.K., Stepanjuk I.A. 1974. - Morskaja gidrometrija. Muromcev A.M. (ed.) Gidromieteoizdat, Leningrad (in Russian).

Eishandbuch für die Schiffahrt in der Ostsee und den benachbarten Gewässern, 1974. - VEB Schiffsversorgung, Rostock.

Girjatowicz J.P. 1981. — Zjawiska lodowe na Jeziorze Dabie i w rejonie uj śsia Odry. [Ice phenomena on Lake Dabie and in the vicinity of Odra river mouth]. Wiadomo śoci IMGW, 1-2, 111-128 (in Polish).

Girjatowicz J.P. 1983. — Zjawiska lodowe u polskiego wybrżeza Baltyku oraz ich wplyw nażegluge i rybolówstwo. [Ice phenomena along the Polish Baltic coast and their effects upon navigation and fishing]. Rozprawy nr 91. Wyd. Akademia Rolnicza, Szczecin (in Polish).

Girjatowicz J.P. 1990. — Atlas zlodzenia wód polskiego wybrżeza Baltyku. [Ice cover atlas for Polish Baltic coastal waters]. Wyd. Akademii Rolniczej, Urzedu Morskiego i Okregowego Przedsiebiorstwa Geodezyjno-Kartograficznego. Szczecin (in Polish).

Girjatowicz J.P. 1994. — Zjawiska lodowe na Zalewie Wiślanym. [Ice condition in the Vistula Lagoon]. Przeglad Geograficzny, 1-2, 119-132 (in Polish).

Girjatowicz J.P. 2001a. — Charakterystyki zlodzenia polskich jezior przybrzeżnych. [Ice characteristics of Polish coast lakes]. Inżynieria Morska i Geotechnika, 2, 73-76 (in Polish).

Girjatowicz J.P. 2001b. — Effects of atmospheric circulation on ice conditions in the Southern Baltic coastal lagoons. Int. J. Climatol., 21, 1593-1605.

Girjatowicz J.P. 2001c. - Morfologia i topografia pokryw lodowych na polskim wybrżezu Baltyku. [Morphology and topography of the ice covers along the Polish Baltic coast]. Przegl. Geogr. 1-2, 25-36 (in Polish).

Girjatowicz J.P. 2001d. - Studies on the formation and disintegration of grounded ice hummocks in sheltered areas of the southern Baltic coast. Oceano.l Studies, 3-4, 3-16.

Girjatowicz J.P. 2003. - The influence of the North Atlantic Oscillation on ice conditions in coastal lakes of the Southern Baltic Sea. Ann. Limnol. - Int. J. Lim., 39, 71-80.

Girjatowicz J.P. \& Kożuchowski K.M. 1995. - Contemporary changes of Baltic Sea ice. Geographia Polonica, 65, 43-50.

Golek J. 1973. — Termika i zlodzenie wód. [Thermology and ice conditions]. In: Atlas Narodowy Polski, Warszawa (in Polish).

Golek J. 1986. — Zjawiska lodowe na rzekach i jeziorach. [Ice phenomena on rivers and lakes]. In: Atlas Hydrologiczny Polski, Wyd. Geologiczne, Warszawa (in Polish).

Jańczak J. 1997. - Atlas jezior Polski. [Atlas of Polish Lakes]. Wyd. $I M G W$, Poznań (in Polish).

Kajak Z. 1995. - Hydrobiologia, ekosystemy wód sródladowych. [Hydrobiology, ecosystems of inland waters]. Dzial Wydawnictw Filii UWw Bialymstoku (in Polish).

Keinonen A., 1976. - The shape and size of ice ridges in the Baltic according to measurements and calculations. Styrelsen för Vintersjöfartsforskning (Winter Navigation Research Board). Research Report, 17, Helsinki.

Keinonen A. 1977. - Measurements of phisical characteristics of ridges on April 14 and 15, 1977. Styrelsen för Vintersjöfartsforskning (Winter Navigation Research Board), 22, Helsinki.

Koslowski G. \& Glaser R. 1999. - Variations in reconstructed ice winter severity in the western Baltic from 1501 to 1995 and their implications for the North Atlantic Oscillation. Climatic Change, 41, 175-191.

Kożuchowski K. 1995. - Glebokie cyklony, antycyklony i cyrkulacja strefowa nad Europa (1900-1990). [Deep cyclones, anticyclones and zonal circulation over Europe (1900-1990)]. Przeglad Geofizyczny, 3, 231-246 (in Polish).

Lampert W. \& Sommer U. 1996. — Ekologia wód śódladowych. [Ecology of inland waters]. Państwowe Wydawnictwo Naukowe, Warszawa (in Polish).

Leppäranta M. 1998. - Investigation of the Physics of the Winter Season in the Baltic Sea. Materialy, Konferencje, 36, In: Problemy fizyczne ekologii wód naturalnych. Uniwersytet Szczecinski, Szczecin, 25-37.

Leppäranta M. 1999. - Ice thickness mapping in the Baltic Sea. Publicationes Instituti Geographici Universitatis Tartuensis, 84, 16-25.

Leppäranta M. \& Seina A. 1985. — Freezing, maximum annual ice thickness and breakup of ice on the Finnish coast 1830-1984. Geophysica, 21, 87-104. 
Lundbec - Eisschiebungen am Kurischen Haff. Natur und $M u$ seum, 61, Frankfurt a. M., 36-40.

Lomnicki A. 1999. - Wprowadzenie do statystyki dla przyrodników. [Introduction in of statistics for scientists]. Wydawnictwo Naukowe PWN, Warszawa (in Polish).

Malicki J. \& Mietus M. 1994. - Klimat. [Climate]. In: Atlas Morza Baltyckiego. Majewski A. \& Lauer Z. (eds.), Wyd. Instytutu Meteorologii i Gospodarki Wodnej, Warszawa, 60-69 (in Polish).

Maliński J. 1971. - Zlodzenie Zalewu Szczecinskiego i wód przyleglych. [Ice conditions on the Szczecin Lagoon and adjacent waters]. Materialy PIHM. Wyd. Komunikacji i Laczności, Warszawa (in Polish).

Manninen T. 1996. - Microwave surface backscattering and surface roughness of Baltic sea ice. Finnish Marine Research, 265.

Marsz A. 1995. - Wskaznik oceanizmu jako miara klimatycznego wspóloddzialywania w systemie ocean-atmosfera-kontynenty. [Index of oceanicity as a measure of climatical interaction in the system ocean-atmosphere-continents]. Wydawnictwo Wższej Szkoly Morskiej, Gdynia (in Polish).

Palosuo E. 1975. - The formation and structure of Ice Ridges in the Baltic. Styrelsen för Vintersiöfartsforskning (Winter Navigation Research Board). Research Report, 12, Helsinki.

Palosuo E. 1976. - Experiments with a narrow beam sonar for studing ice ridges. Styrelsen för Vintersjöfartsforskning (Winter Navigation Research Board), 14, Helsinki.

Paslawski Z. 1982. — Zlodzenie jezior w Polsce. [Ice conditions of the lakes in Poland]. Przeglad Geofizyczny, 1-2, $79-92$ (in Polish).

Reinhard H. 1955. - Eispressungen der Küste. Wissenschaftliche zeitschrift der Ernst Moritz Arndt - Universität Greifswald, $4(6 / 7)$.

Seina A. \& Palouso E. 1993. - The classification of the maximum annual extent of ice cover in the Baltic Sea. Meri 20, Helsinki, $5-20$

Sergeyeva L.G. 1983. — Metodika prognozirovaniya vesennych ledovych faz v Kurshskom i Kaliningradskom zaliwach. [Methodics forecast of ice phase spring in the Curonian and Kaliningrad Lagoons]. Pages 64-70 in Abuzyarov Z. K. (ed). Calculation and forecast regime sea elements. Gidrometeoizdat, Leningrad (in Russian).

Slaucitajs L. 1929. — Spaltenbildung in der Eisdecke und Eisschiebungen an der Küste des Rigaschen Meerbusens im Winter 1928/29. Annalen d. Hydr. U. Mar. Met., 57, 411-414.
Stańczykowska A. 1990. — Ekologia naszych wód. [Ecology of our waters]. Wyd. Szkolne i Pedagogiczne, Warszawa (in Polish).

Stopa-Boryczka M., Boryczka J., Kucińska B. \& Zmudzka E. 1990. - Atlas wspólzależnósci parametrów meteorologicznych i geograficznych w Polsce. [Atlas of interdependence of meteorological and geographical parameters in Poland]. VI, Wyd. Uniwersytetu Warszawskiego, Warszawa (in Polish).

Stopa-Boryczka M., Boryczka J., Wagrowska M. \& Smialkowski J. 1994. - Atlas wspólzależności parametrów meteorologicznych i geograficznych w Polsce. [Atlas of interdependence of meteorological and geographical parameters in Poland]. VIII, Wyd. Uniwersytetu Warszawskiego, Warszawa (in Polish).

Szefler K. 1993. — Zlodzenie. [Ice conditions]. In: Zatoka Pucka. Wyd. Uniwersytetu Gdanskiego, Gdańsk, 112-134 (in Polish).

Udin I.\& Ullerstig A. 1976. - A numerical model for forecasting the ice motion in the Bay und Sea of Bothmia. Styrelsen för Vintersjöfartsforskning (Winter Navigation Research Board), 18, Helsinki.

Wadhams P. 1996. — Sea Ice Morphology. In: Physics of Ice-Covered Seas. Lecture Notes from a Summer School in Savonlinna. University of Helsinki, Helsinki, 231-288.

Wetzel R.G. 1975. - Limnology. W.B. Saunders Company, Philadelphia-London-Toronto.

WMO SEA-ICE Nomenclature 1970. - WMO No. 259, Tp. 145, Geneva, Switzerland.

Woś A. 1967. - Zagadnienie kontynentalizmu i oceanizmu termicznego klimatu w świetle izoanomal rocznej amplitudy temperatury powietrza. [The problem of thermal continentalism and oceanism in the light of izoanomals of annual amplitudes of air temperature]. Przeglad Geograficzny 2, 367-374 (in Polish).

Zakrzewski W. \& Szefler K. 1984. — Zlodzenie Zatoki Puckiej. [Ice conditions on the Puck Bay]. Zeszyty Naukowe BiNoZ Uniwersytetu Gdańskiego, Oceanografia 10, 97-120 (in Polish).

Zimdars U. 1941. - Die Fischerei des Stettiner Haffs und seiner Nebengewässer. Jahrb. d. Pomm. Geogr. Gesellsch., 59/60, Greifswald.

Zorina W.A. \& Maliński J. 1975. — Zlodzenie. [Ice conditions]. Pages 318-359 in Hydrometeorologiczny ustrój Zalewu Wiślanego. Lazarienko N. N. \& Majewski A. (eds.). Wyd. Komunikacji i Lacznosci, Warszawa. (in Polish). 